\title{
Vulnerability assessment of storm surges in the coastal area of Guangdong Province
}

\author{
K. $\mathbf{L i} \mathbf{i}^{1,2}$ and G. $\mathbf{S} . \mathbf{L i} \mathbf{i}^{1}$ \\ ${ }^{1}$ Institute of Geographic Sciences and Natural Resources Research, CAS, Beijing 100101, China \\ ${ }^{2}$ Graduate University of Chinese Academy of Sciences, Beijing 100049, China
}

Received: 4 January 2011 - Revised: 31 May 2011 - Accepted: 13 June 2011 - Published: 20 July 2011

\begin{abstract}
Being bordered by the South China Sea and with long coastline, the coastal zone of Guangdong Province is often under severe risk of storm surges, as one of a few regions in China which is seriously threatened by storm surges. This article systematically analyzes the vulnerability factors of storm surges in the coastal area of Guangdong (from Yangjing to Shanwei). Five vulnerability assessment indicators of hazard-bearing bodies are proposed, which are social economic index, land use index, eco-environmental index, coastal construction index, and disaster-bearing capability index. Then storm surge vulnerability assessment index system in the coastal area of Guangdong is established. Additionally, the international general mode about coastal vulnerability assessment is improved, and the vulnerability evolution model of storm surges in the coastal area of Guangdong is constructed. Using ArcGIS, the vulnerability zoning map of storm surges in the study region is drawn. Results show that there is the highest degree of storm surge vulnerability in Zhuhai, Panyu, and Taishan; second in Zhongshan, Dongguan, Huiyang, and Haifeng; third in Jiangmen, Shanwei, Yangjiang, and Yangdong; fourth in Baoan, Kaiping, and Enping; and lowest in Guangzhou, Shunde, Shenzhen, and Longgang. This study on the risk of storm surges in these coastal cities can guide the land use of coastal cities in the future, and provide scientific advice for the government to prevent and mitigate the storm surge disasters. It has important theoretical and practical significance.
\end{abstract}

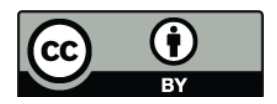

Correspondence to: $\mathrm{G}$. S. Li (ligs@igsnrr.ac.cn)

\section{Introduction}

Storm surges are oscillations of the water level in a coastal or inland water body in the period range of a few minutes to a few days, resulting from forcing from the atmospheric weather systems (i.e., it's the difference between the observed water level and the predicted astronomical tide). With global warming and sea-level rising, storm surge disasters have a trend of increasing in intensity and frequency. For example, an extraordinarily serious storm surge triggered by the earthquake and tsunami from the Indian Ocean hit Indonesia in December 2004, causing more than 300 thousand deaths and disappearances, which is the most serious storm surge disaster in human history. In August 2005, hurricane Katrina attacked New Orleans in America, leading to a huge storm surge disaster that caused 1069 deaths and more than 100 billion dollars of economic losses. Storm surge is the most serious marine disaster in China, causing heavy losses to human life and property every year (Feng, 1982). Available data show that the economic loss caused by the storm surge disasters is much heavier than that caused by any other marine disasters in China, and the loss from the severe storm surge disasters is the highest (Yang et al., 1994). In August 2006, typhoon "Saomei" landed in Cangnan county of Zhejiang Province, resulting in a serious storm surge disaster that caused 326 deaths and 7.1 billion yuan of economic losses. Lately, Japan's most powerful earthquake since records began struck the north-east coast, triggering a massive tsunami. The terrible disaster caused a huge death toll of more than 12000 and an enormous economic loss of 10 billion dollars. The coastal area of Guangdong Province is a region faced with the most serious storm surges in China. During the past century a dozen particularly serious

Published by Copernicus Publications on behalf of the European Geosciences Union. 
storm surge disasters occurred in Guangdong Province, causing enormous loss of human life and poverty. Since 1949 Guangdong Province has been attacked by tropical cyclones 5-6 times a year. The storm surge disasters mainly occur in three regions: Shantou Area, the Pearl River Delta, and the Leizhou Peninsula and Zhanjiang Area (Lu, 1984).

The study area in this paper plays an important role in Guangdong Province and China. Many researchers have analyzed the characteristics of severe storm surge disasters in history and done loss assessment (Zhang et al., 2008; Zhao et al., 2007). In particular, research on effect of sea-level rising is very prominent in China (Huang et al., 2001; Li et al., 1993). In the past $20 \mathrm{yr}$ these research efforts in many different disciplines have developed many valuable results generated from diversified aspects such as ecology, biology, and oceanography, etc. However, so far few studies have focused on vulnerability assessment of storm surge disasters. This article attempts to establish a method to evaluate the vulnerability of storm surge disasters in Guangdong Province. It is meaningful for the government to draw up the urban development planning and the emergency response plan.

Vulnerability is broadly defined as "the potential for loss." However, there are numerous literature but not always corresponding definitions. So vulnerability remains one of the most difficult aspects in quantity hazard research and often heavily relies on indicators from available mass data such as census. As such, current vulnerability assessments do not take into account all of the possible pressures related to diminished capacity and decreased resilience (King and Mac Gregor, 2000). Many influential writers have seen vulnerability as one of the keys to understanding disaster because it is correlated with the underprivileged, past losses, and susceptibility to future losses (Blaikie et al., 1994; Cutter 1996a, 1996b). In 1982, United Nations Disaster Relief Organization proposed that vulnerability is the susceptibility to damage or injury. Kasperson et al. (1995) proposed that vulnerability is a product of three dimensions: exposure, resistance (the ability to withstand impacts), and resilience (the ability to maintain basic structures and to recover from losses). Heinz Center in 2002 proposed that vulnerability depends on the sensitivity of the natural and social system, adaptability, and the degree of exposure to disasters; and is seen as the degree to which a system will respond to a given hazard event and the degree to which adjustments can moderate or offset potential damage. White and Hass (1975) considered that nations vulnerability to natural hazards in being increased by four factors. Branch et al. (1984) and Taylor (1990) highlighted community resources, social organization, and indicators of individual as well as lifestyles, attitudes, and values as major factors to show resilience in the face of danger. Kanbur and Squire (2001) took into account both exposure to serious risk and defenselessness against deprivation. Vale and Campanella (2005) proposed that variations and impediments in recovery time were the important concepts in vulnerability. Drawing from the numerous definitions mentioned above, it is clear that social inequities along the lines of class, race, ethnicity, gender, age, and national origin are key elements in people's vulnerability to environmental calamities.

\section{Study area}

The study area is in the middle part of coastal areas of Guangdong Province, southeast of China (Fig. 1). It is located at $21^{\circ} 33^{\prime}-23^{\circ} 25^{\prime} \mathrm{N}$ and $110^{\circ} 42^{\prime}-115^{\circ} 37^{\prime} \mathrm{E}$, including nine big cities-Guangzhou, Shenzhen, Dongguan, Zhongshan, Zhuhai, Foshan, Jiangmen, Huizhou, and Yangjiang. With more than $2.9 \times 10^{4} \mathrm{~km}^{2}$ and about 20 million of population, most of which comes from other less developed areas of China, this region whose gross domestic product amounts to $68.4 \%$ of the whole Province is well known for its economy growth and economy status in China. Hence, it is significant and meaningful for the researchers to study the storm surge disasters in the study area.

There are a lot of tributaries widely distributed in the study area and its terrain is generally low. There are more than $7.7 \times 10^{6}$ acres of arable lands, about one third of them are $1.0 \mathrm{~m}$ under the base surface of Pearl River. For example, the elevation of Guangzhou in total is between $1.5-2.5 \mathrm{~m}$, and the whole city is completely protected by embankments and croplands from the storm surge disasters. It is so easy to be submerged by storm surges that the whole region has to defend serious threat from storm surge disasters every year. The government has done much work on the defense and it is urgent for the region to establish an effective disaster prevention system.

\section{Assessment index system and methods}

The vulnerability from storm surges occurs at least in three different ways. First, there is the inundation of the land by ocean water, pushed up by tangential wind stress at the ocean surface by the wind field associated with the cyclone (Murty, 1984). Second, strong winds from cyclones usually bring on tremendous damage to the coastal structures. Third, heavy precipitation from cyclones can cause flooding in rivers. In this study, only the first two physical effects are considered. Based on the study of evaluation of submerged scope by storm surges in study area, this article attempts to establish a synthesized assessment index system of vulnerability to storm surges.

\subsection{Data processing}

The evaluation object of vulnerability to storm surges is a complex system, which includes many aspects such as economy, industry, agriculture, environment, ecology, and population, etc. Data sources are very complicated, so it is necessary to carry out reliability test on the historical data and 


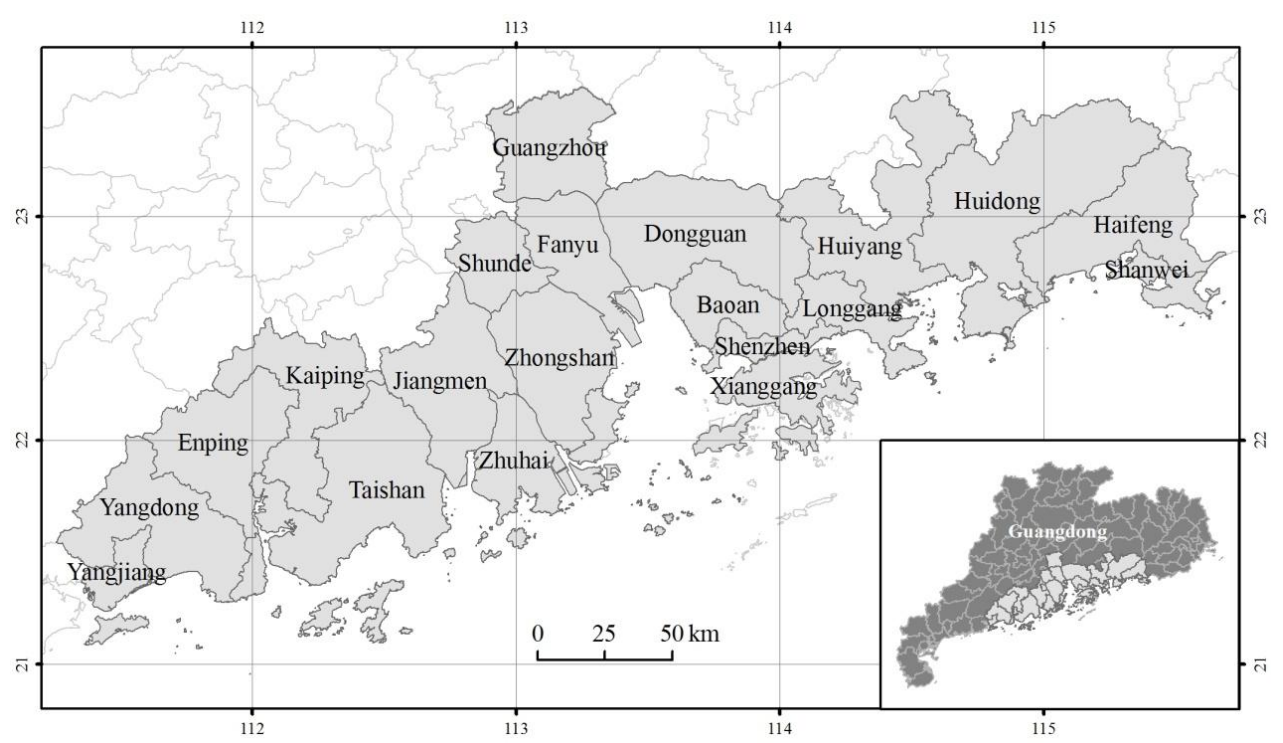

Fig. 1. Study area ranged from Yangjiang to Shanwei in Guangdong Province.

status information to avoid the distortion of double counting. In order to actually reflect the response of the hazard-bearing bodies to storm surge disasters, the collected data must be preprocessed.

The social and economic data are counted up by townships as the smallest statistical units, except for a few regions in which data of counties and districtsis are counted up. Finally, we set counties and districts as the standard statistical unit. The natural environment data is calculated by area, including areas of land, beach, arable land, and aquaculture. Ports and moisture embankments are counted by scale or length. The evaluation units are not unified, so two methods are applied to preprocess the data, that is, weighted average method and principal component method.

\subsection{Assessment index system}

Many factors can affect the vulnerability to storm surges. Some researchers put forward 7 factors, for example, population, architecture, land, industry, agriculture, lifeline, assets, and so on. Considering the numerous species of hazardbearing bodies, it is difficult to constantly partition them, and there has been no common knowledge of species of hazard-bearing bodies until now (Yang et al., 2000). Some researchers propose that the assessment indexes could be divided into two parts: natural indexes and humanistic indexes. Some other researchers put forward that it should be partitioned into socioeconomic indexes and attributes of hazardsuffering bodies. The socioeconomic indexes include population, resources, environment, infrastructure, and assets, etc. The attributes of hazard-bearing bodies involve types, quantity, value, and loss ratios. There are many different vulnerable factors for different hazard-bearing bodies. It is needed to find out the principle factors of vulnerability which have crucial impact on the vulnerability assessment.

The vulnerability of storm surges refers to the capacity to be wounded, i.e., the degree to which a system is likely to experience harm due to exposure to storm surges. For one region, the vulnerability assessment indexes may be different when it faces different disasters. But the indexes are essentially the same, and just the selection standards are different. According to the features of storm surge disasters, vulnerability assessment indexes are divided into five parts: social economic index, land use index, eco-environmental index, coastal construction index, and disaster-bearing capability index.

The social economic index is the most important, because the concept of vulnerability is closely connected with humans and society. Without humans and society, vulnerability assessment is meaningless. In the coastal area of Guangdong Province the social economic factors are threatened by storm surge disasters immediately and it should be considered preferentially. The social economic index includes factors of population, industrial output value, agricultural output value, buildings, roads, and so on. The land use index is secondly important, because storm surge disasters usually cause flooding and strong winds that submerge the land and damage the plants. The vulnerability of land and plants is an indispensable part, having great impact on the vulnerability assessment of storm surges. Factors considered in land use index are farming, forestry, aquaculture, and salt industry. The eco-environmental index is thirdly important, because the environment and ecosystem are important in order for humans to live and develop. When storm surges occur, the environment and ecosystem in the coastal area of Guangdong Province are seriously damaged, restricting 


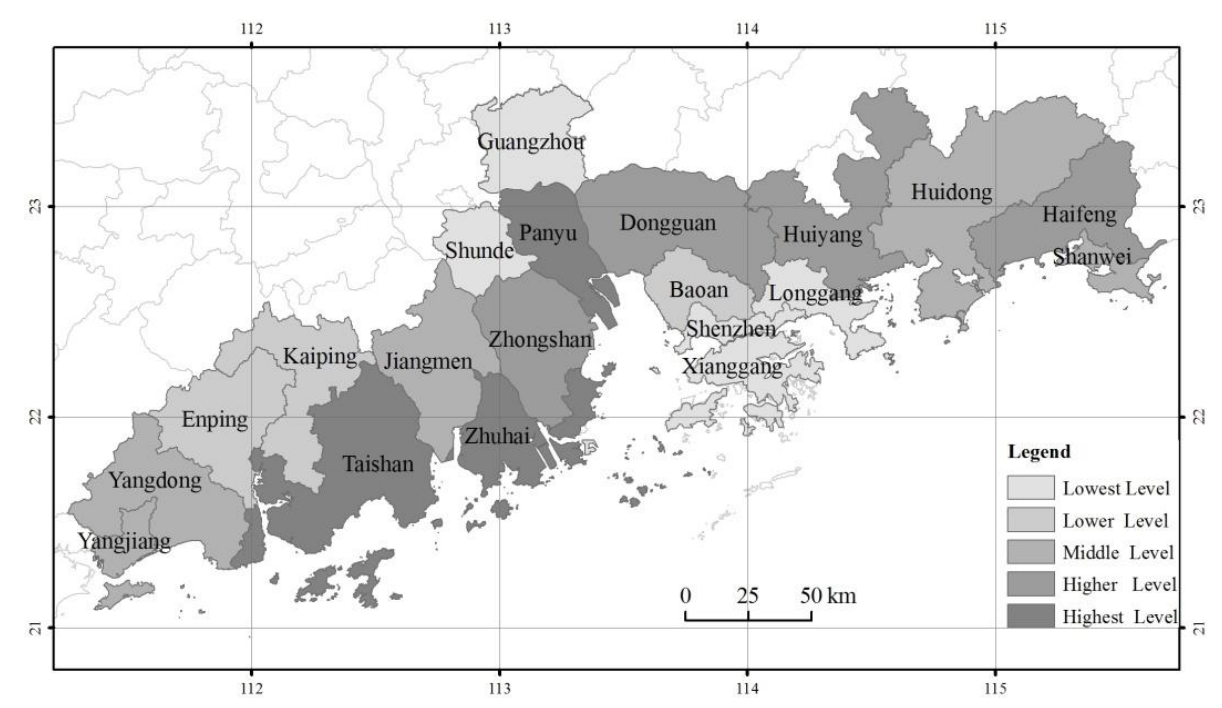

Fig. 2. The vulnerability-to-storm-surges assessment result in the coastal counties and districts of Guangdong Province.

the sustainable development of Guangdong. So it is necessary to consider the eco-environmental factors. The ecoenvironmental index counts in factors of beaches, wetlands, and mangroves. Besides the above three indexes, there are two more special indexes for vulnerability assessment of storm surges. The coastal construction index is mainly about the construction and architecture near the coastline that are threatened by huge waves. Storm surge is different from other disasters, at it usually causes strong wind and huge waves. So it is important to consider the impact of waves and wind on the coastline. The coastal construction index considers factors of seawalls, harbors, wharfs, and coastal facilities. The disaster-bearing capability index is mainly about the capability that the government and society bears to resist storm surge disasters. It is opposite to the above four indexes. It is an indispensible part for the vulnerability assessment of storm surge disasters in Guangdong Province. The disasterbearing capability index takes factors of financial revenue, investment of tide-prevention engineering, and labor population into account.

The factors mentioned above can be subdivided into more detailed elements. For example, the population factor can be calculated by attributes of total number, density, educational level, and age structure. The industrial output value factor contains attributes of gross value and per-capita value. These attributes of factors cover all aspects of vulnerability of storm surge disasters in a coastal area. In summary, the vulnerability assessment index system of storm surge disasters in the coastal area of Guangdong Province is established (Table 1).

\subsection{Assessment method}

The hazard-bearing bodies of storm surges are mainly distributed in the coastal zone. It is very similar to the research on vulnerability of coastal zone where hazard-bearing bodies primarily distribute. Similar to the research on vulnerability of coastal zone, the vulnerability assessment of storm surges was usually confused with the fragility evaluation of coastal zone by many researchers. There are a large number of researchers in costal countries who have conducted studies on fragility evaluation of coastal zone in depth. But there are very few studies on vulnerability assessment of storm surges. The two kinds of studies have a few similarities and also many differences. First, their study areas are almost the same, that is, the coastal zone. Second, the methods of vulnerability assessment are similar. The biggest difference is the disaster-causing factor. The study objects of coastal vulnerability under global change are mainly about exposure and fragility caused by sea-level rise, which involves coastal erosion, saltwater intrusion, storm surge inundation, loss of wetlands, etc. The research of storm surge vulnerability focuses on the capacity to be wounded and the degree to which a system is likely to experience harm due to exposure to storm surges. Considering this situation, in order to clarify the nature of vulnerability of storm surges, the study on vulnerability assessment index system of storm surges should be strengthened.

As mentioned above, the vulnerability assessment indexes are divided into five parts: social economic index, land use index, eco-environmental index, coastal construction index, and disaster-bearing capability index. So far, different models of vulnerability evaluation are proposed. The model of Coastal Vulnerability Assessment proposed by Gornitz is thought to be an appropriate method for most vulnerability assessment of coastal disasters. The assessment method has been perfected with years of development, tested in practical applications many times and the results proven credible. 
Table 1. Vulnerability assessment index system of storm surge disasters.

\begin{tabular}{|c|c|c|c|}
\hline Index & Factor & Element & Introduction \\
\hline \multicolumn{4}{|c|}{ Vulnerability assessment index system } \\
\hline \multirow[t]{11}{*}{$\begin{array}{l}\text { Social economic } \\
\text { index }\end{array}$} & \multirow[t]{4}{*}{ Population } & Total number & $\begin{array}{l}\text { the total numbers of population } \\
\text { in the evaluation units }\end{array}$ \\
\hline & & Density & $\begin{array}{l}\text { the densities of population in } \\
\text { the evaluation units }\end{array}$ \\
\hline & & Age structure & $\begin{array}{l}\text { the proportions of the } \\
\text { aged, young, and children }\end{array}$ \\
\hline & & Educational level & $\begin{array}{l}\text { the proportion of population } \\
\text { of high school education } \\
\text { and above }\end{array}$ \\
\hline & \multirow[t]{2}{*}{ Roads } & Density & $\begin{array}{l}\text { the ratio between road mileage } \\
\text { and land area }\end{array}$ \\
\hline & & Road grade & the constitute of road grades \\
\hline & \multirow[t]{3}{*}{$\begin{array}{l}\text { Industrial and } \\
\text { agricultural } \\
\text { output value }\end{array}$} & Industrial output value & $\begin{array}{l}\text { the industrial output values in } \\
\text { the evaluation units }\end{array}$ \\
\hline & & Agricultural output value & $\begin{array}{l}\text { the agricultural output values in } \\
\text { the evaluation units }\end{array}$ \\
\hline & & Per-capita output value & $\begin{array}{l}\text { the ratio between output value } \\
\text { and population }\end{array}$ \\
\hline & \multirow[t]{2}{*}{ Residential land } & Area & $\begin{array}{l}\text { the area of residential land in } \\
\text { the evaluation units }\end{array}$ \\
\hline & & Ratio of urban residential land & $\begin{array}{l}\text { the proportion of land area for } \\
\text { urban residents }\end{array}$ \\
\hline \multirow[t]{3}{*}{ Land use index } & Farming land & Area & $\begin{array}{l}\text { the area of farming land in the } \\
\text { evaluation units }\end{array}$ \\
\hline & Aquaculture & Area & $\begin{array}{l}\text { the area of aquaculture land in } \\
\text { the evaluation units }\end{array}$ \\
\hline & Arable land & Ratio of low-lying arable land & $\begin{array}{l}\text { the proportion of low-lying } \\
\text { arable land in the evaluation } \\
\text { units }\end{array}$ \\
\hline \multirow[t]{4}{*}{$\begin{array}{l}\text { Eco-environmental } \\
\text { index }\end{array}$} & \multirow[t]{2}{*}{$\begin{array}{l}\text { Beaches and } \\
\text { wetlands }\end{array}$} & Area & $\begin{array}{l}\text { the area of beaches and } \\
\text { wetlands in the evaluation units }\end{array}$ \\
\hline & & Ratio of beaches & $\begin{array}{l}\text { the proportion of beaches in the } \\
\text { evaluation units }\end{array}$ \\
\hline & mangroves & Area & $\begin{array}{l}\text { the area of mangroves in the } \\
\text { evaluation units }\end{array}$ \\
\hline & Rivers & Density & $\begin{array}{l}\text { the ratio between river length } \\
\text { and land area }\end{array}$ \\
\hline \multirow{4}{*}{$\begin{array}{l}\text { Coastal } \\
\text { construction } \\
\text { index }\end{array}$} & \multirow[t]{2}{*}{$\begin{array}{l}\text { Coastal } \\
\text { engineering }\end{array}$} & Harbors and wharfs & $\begin{array}{l}\text { the scale of harbors and wharfs } \\
\text { in the evaluation units }\end{array}$ \\
\hline & & Tide-prevention engineering & $\begin{array}{l}\text { the ratio of tide-prevention } \\
\text { engineering in low grade }(<20 \mathrm{a} \\
\text { return period })\end{array}$ \\
\hline & Coastal highways & Ratio of highways & $\begin{array}{l}\text { the proportion of coastal } \\
\text { highways within } 5 \mathrm{~km} \text { in the } \\
\text { coastal zone }\end{array}$ \\
\hline & Coastal buildings & Density & $\begin{array}{l}\text { the density of coastal buildings } \\
\text { in the evaluation units }\end{array}$ \\
\hline \multirow{4}{*}{$\begin{array}{l}\text { Disaster-bearing } \\
\text { capability index }\end{array}$} & \multirow[t]{2}{*}{ Seawalls } & Completion rate & the rate of seawalls completed \\
\hline & & Ratio of seawalls & $\begin{array}{l}\text { The ratio between seawalls } \\
\text { length and coastline length }\end{array}$ \\
\hline & Labor population & Ratio of labor & $\begin{array}{l}\text { the proportion of labor } \\
\text { population in the evaluation } \\
\text { units }\end{array}$ \\
\hline & Financial revenue & Gross income & $\begin{array}{l}\text { the gross financial revenue in } \\
\text { the evaluation units }\end{array}$ \\
\hline
\end{tabular}


Table 2. The vulnerability indexes of storm surges in 19 coastal counties and districts of Guangdong Province.

\begin{tabular}{lllllll}
\hline & $\begin{array}{l}\text { Social economic } \\
\text { index }\end{array}$ & $\begin{array}{l}\text { Land use } \\
\text { index }\end{array}$ & $\begin{array}{l}\text { Eco-environmental } \\
\text { index }\end{array}$ & $\begin{array}{l}\text { Coastal construction } \\
\text { index }\end{array}$ & $\begin{array}{l}\text { Disaster-bearing } \\
\text { capability index }\end{array}$ & $\begin{array}{l}\text { Vulnerability } \\
\text { index }\end{array}$ \\
\hline Yangjiang & 3.5 & 2.25 & 3.92 & 3.5 & 3.5 & 5.56 \\
Yangdong & 2.61 & 4.33 & 2.25 & 1.83 & 1 & 6.82 \\
Enping & 2.07 & 3.5 & 2.67 & 1.83 & 1.42 & 4.99 \\
Kaiping & 3.32 & 3.08 & 3.08 & 1.83 & 2.25 & 5.06 \\
Taishan & 3.86 & 5.17 & 3.92 & 4.75 & 3.08 & 11 \\
Jiangmen & 2.79 & 4.75 & 3.08 & 3.5 & 4.33 & 5.74 \\
Zhuhai & 3.5 & 4.33 & 5.58 & 4.75 & 4.75 & 9.2 \\
Zhongshan & 3.68 & 4.75 & 5.17 & 3.08 & 4.75 & 7.65 \\
Guangzhou & 4.75 & 3.08 & 1.42 & 2.67 & 5.58 & 3.15 \\
Panyu & 3.14 & 4.75 & 4.75 & 4.33 & 5.58 & 8.42 \\
Dongguan & 4.57 & 4.33 & 3.5 & 4.75 & 5.58 & 7.68 \\
Shenzhen & 4.57 & 1 & 3.08 & 5.17 & 4.33 & 3.61 \\
Baoan & 3.68 & 2.67 & 2.25 & 4.33 & 3.5 & 4.7 \\
Longgang & 3.68 & 1.83 & 2.67 & 2.67 & 2.25 & 3.7 \\
Huiyang & 2.79 & 5.17 & 2.67 & 3.5 & 2.25 & 7.74 \\
Huidong & 2.79 & 3.92 & 2.67 & 3.5 & 2.25 & 6.74 \\
Shanwei & 2.96 & 1.83 & 4.75 & 3.5 & 3.92 & 6.33 \\
Shunde & 3.86 & 3.08 & 2.67 & 3.83 & 2.67 & 3.85 \\
Haifeng & 2.79 & 3.92 & 4.75 & & & 7.74 \\
\hline
\end{tabular}

Coastal Vulnerability Assessment Model (Gornitz, 1991):

$\mathrm{CVI}=\left[\frac{x_{1} \cdot x_{2} \ldots x_{n}}{n}\right]^{\frac{1}{2}}$

In the formula, CVI is the index of coastal vulnerability; if the CVI is bigger, the potential loss caused by coastal disasters would be greater. $X$ represents the different assessment factors; $n$ represents the number of assessment factors.

Comparing the different models of vulnerability evaluation, the advantages and disadvantages of each model are found out and the essence of vulnerability evaluation is grasped. Then a conceptual model of comprehensive evaluation of storm surges vulnerability in the coastal area of Guangdong is established:

$V=f(A \cdot L \cdot E \cdot C)$

where $V, A, L, E, C$ and $K$ is vulnerability index, social economic index, land use index, eco-environmental index, coastal construction index, and disaster-bearing capability index, respectively.

Based on the conceptual model, the model of Coastal Vulnerability Assessment is improved to adapt the characteristics of storm surges. Four indexes - social economic index, land use index, eco-environmental index and coastal construction index - are used to reflect the basic features of disaster-bearing bodies when they are faced with storm surge disasters. The disaster-bearing capability index represents the ability that the disaster-bearing bodies have to resist the damage of storm surges. So there is an inverse relation between the two kinds of indexes. According to the relationships between these indexes and combination with Coastal Vulnerability Assessment Model, the model of vulnerability of storm surges in the coastal area of Guangdong is established:

$V=\left[\frac{A \cdot L \cdot E \cdot C}{K}\right]^{\frac{1}{2}}$

where variables definition is the same as that in conceptual model. As described in Table 1, each index includes a certain number of factors which have several attributes. Calculations of these evaluation indexes are based on the elements of each assessment factor. According to correlation among these elements, the most relevant elements are selected. For the social economic index, 7 elements are chosen: population density, road density, road grade, industrial output value, agricultural output value, per-capita output value, and ratio of urban residential land. The model is conducted to evaluate the value of social economic index as follows:

$$
\begin{aligned}
& A=f \frac{1}{7} \sum_{i=1}^{7} \alpha_{i j} \\
& \alpha_{i j}=\frac{5 \cdot\left(x_{i j}-x_{\min }\right)}{x_{\max }-x_{\min }}+1(i=1,2, \ldots 7 ; j=1,2, \ldots 19)
\end{aligned}
$$

$A_{j}$ is the social economic index; $a_{i j}$ represents the scores in each factor which is classified into five grades; $x_{i j}$ is the 
value of each element; $i$ is the number of elements; and $j$ is the number of evaluation units. With the same method, the evaluation models of land use index, eco-environmental index, coastal construction index, and disaster-bearing capability index are respectively conducted.

\section{Assessment and conclusion}

\subsection{Vulnerability assessment}

The coastal region of Guangdong Province is a region seriously threatened by storm surges in China. To make the vulnerability assessment more reasonable, the study area (from Yangjiang to Shanwei), which is the most dangerous part of this region in history, is divided into 19 counties and districts on the basis of administrative division of Guangdong Province. According to the data collected from bureaus of statistics, the value of evaluation factors in each statistical unit (county or district) is counted up. As described in Sect. 3.3, the fundamental factors are gathered and preprocessed in accordance with the requirements of vulnerability assessment. Applying the evaluation models established above, the values of social economic index, land use index, eco-environmental index, coastal construction index, and disaster-bearing capability index are calculated separately, and the results are shown in Table 2. Based on the values of evaluation indexes, the vulnerability assessment model of storm surges is used to calculate the vulnerability of storm surges in the coastal area of Guangdong Province. Results of vulnerability indexes are from 3.15 to 11 . Because of the highest values of land use index and coastal construction index, the city of Taishan is one of the most vulnerable districts threatened by storm surge disasters in the coastal region of Guangdong Province. Due to the integral protection engineering and the blocking function of Fanyu district, the downtown area of Guangzhou is rated the least vulnerable. Finally, we divide the values of vulnerability indexes into five grades, which respectively represent the highest vulnerable area, the higher vulnerable area, the intermediately vulnerable area, the lower vulnerable area, and the lowest vulnerable area.

Appling the spatial comparison function of GIS, the vulnerability assessment of storm surges in the coastal counties and districts of Guangdong Province is mapped in Fig. 2. The 19 counties and districts in the study area are depicted by five different shades of gray to represent their different vulnerability levels. It shows that Zhuhai, Panyu, and Taishan are classified into the first grade with the highest vulnerability to storm surges in the whole study area; Zhongshan, Dongguan, Huiyang, and Haifeng are in the second grade which has a relative high vulnerability to storm surges; Jiangmen, Shanwei, Yangjiang, and Yangdong are in the third grade which are intermediately vulnerable to storm surges; Baoan, Kaiping, and Enping are in the fourth grade which has low vulnerability to storm surges; Guangzhou, Shunde, Shenzhen, and Longgang are in the fifth grade with the lowest vulnerability to storm surges.

In the study area, Guangzhou, Shenzhen, and Shunde are well developed cities which have highly concentrated populations and the most prosperous economies. According to the assessment, they are the lowest vulnerable regions. Being compared with other districts, they have enough tideprevention engineering and perfect response measures to emergencies. Due to abundant revenue and large numbers of labor population, the three cities could effectively resist most of storm surge disasters. Unless the tide-prevention engineering is broken or the communities are completely destroyed, these cities are safe enough. So they are the lowest vulnerable regions in the coastal area of Guangdong Province. On the other hand, Zhuhai, Panyu, and Taishan are the most vulnerable regions. The major cause is that there are not enough tide-prevention engineering in the three regions. The social economic index, land use index, eco-environmental index, and coastal construction index of the three cities are higher than other districts. When storm surges attack the three regions, they would be the most vulnerable to damage. The vulnerabilities of the other districts are between that of the two regions mentioned above.

\section{Conclusion and discussion}

In summary, the key area for the defense of storm surges should be concentrated in the Pearl River estuary, especially in its west region. The resisting measures could be classified into two types: engineering and non-engineering measures. The engineering measures mainly include tide-prevention engineering, seawalls, ecological protection measures, and so on. Government should invest more funds to strengthen the construction of engineering to improve the defense system to storm surges. A large number of mangroves, metasequoia, and aquatic such as wave dissipation plants should be planted in the coastal zone outside the seawalls to construct an ecological defense line. The non-engineering measures are more complicated and there are three main points. First, the forecasting and early warning system of storm surges should be carried out in the coastal area of Guangdong Province. Second, the government should establish an emergency response system for storm surges to cope with the complicated situation in effect. Third, the communities should be organized to launch various activities or maneuvers to raise their capacity for resisting storm surge disasters, and the citizens should be trained to be familiar with the skills of self-rescue in order to increase the survival possibility when storm surges come up.

The vulnerability to storm surges not only depends on the fragility of natural and socio-economic systems of coastal zones for facing waveswinds and seawater, but is also closely related to the level of protection that humans can carry 
out to resist disasters. It is important to reasonably select the vulnerability indexes. There are a large number of crisscrossed rivers, intensive towns, and complicated microgeomorphology in the coastal zone of Guangdong Province. It is not appropriate to choose vulnerability indexes only from the socio-economic system. All characteristics of coastal zone of Guangdong Province must be considered. For example, the aquaculture factor is more common and significant in coastal zone of Guangdong than in Shandong; the oilfield factor is much more important in Shandong than in Guangdong. So the aquaculture factor must be considered and the oilfield factor could be ignored in Guangdong. This article has chosen the most important factors in Guangdong Province to evaluate the vulnerability of storm surges. There are still many aspects which need to be improved and consummated in the vulnerability assessment index system.

Acknowledgements. This work is supported by National Key Technology R\&D Program (No. 2006BAD20B05). The writers are grateful for the help from Liu Ying, Xue Xinghua and Wang Bingliang. The comments and suggestions made by reviewers have significantly improved the quality of the paper.

Edited by: A. Loukas

Reviewed by: K. Topouzelis and another anonymous referee

\section{References}

Alexander, D.: The Study of Natural Disasters, 1977-1997, Some Reflections on a Changing Field of Knowledge, Disasters, 21, 284-304, 1997.

Blaikie, P., Cannon T., Davis I., and Wisner B.: At Risk: Natural Hazards, People's Vulnerability, and Disasters, New York, Routledge, 1994.

Branch, K., Hooper, D. A., Thompson, J., and Creighton, J. C.: Guide to social assessment, Boulder, CO, West view Press, 1984.

Cannon, T.: Vulnerability Analysis and the Explanation of Natural Disasters, Disasters, in: Development and Environment, edited by: Varley, A., West Sussex, England: John Wiley and Sons, 138-185, 1994.

Crozier, M.: The Terminology of Natural Hazard Assessment, New Zealand J. Geography, 86, 5-7, 1988.

Cutter, S. L.: Vulnerability to environmental hazards, Progress in Human Geography, 20, 529-539, 1996a.

Cutter, S. L.: Societal Responses to Environmental Hazards, Int. Soc. Sci. J., 48, 525-537, 1996b.

Feng S. Z.: Introduction to storm surge. Science Press, pp. 1-23, 1982.

Granger, K.: Developing an understanding of urban geo-hazard risk. Australian Journal of Emergency Management, 13(2), 1317, 1998.

Gornitz, V.: Global coastal hazards from future sea level rise. Palaeo-climatology, Palaeo-ecology (Global and Planetary Change Section), 3(4), 379-398, 1991.
Heinz Center: Human Links to Coastal Disasters, The H. John Heinz III Center for Science, Economics and the Environment, 2002.

Huang, Z. G., Zhang, W. Q., Fan, J. C., Jiang, P. L., Li, Z. H., and Huang, B. S.: Areas Influenced by Sea Level Rise in Zhujiang Delta, Oceanology Etlimnologia Sinica, 32(2), 621-628, 2001.

Kanbur, R. and Squire, L.: The Evolution of Thinking about Poverty: Exploring the Interactions, in: Frontiers of Development Economics: The Future in Perspective, edited by: Meier, G. and Stiglitz, J., New York, World Bank and Oxford University, 183-226, 2001.

Kasperson, J. X., Kasperson, R. E., and Turner, III, B. L.: Regions at Risk: Comparisons of Threatened Environments, Tokyo: United Nations University Press, 1995.

King, D. and MacGregor, C.: Using social indicators to measure community vulnerability to natural hazards, Australian Journal of Emergency Management, Spring, 52-57, 2000.

Li, P. R., Fang, G. X., and Huang, G. Q.: Impacts on Sea Level Rising on the Economic Development of Zhujiang Delta and Countermeasures, Acta Geographica Sinica, 48(6), 527-534, 1993.

Lu, R.: Historical Tidal Disasters in China. China Ocean Press, Beijing, China, 1-13, 1984.

Murty, T. S.: Storm surges-meteorological ocean tides. Canadian bulletin of fisheries and aquatic sciences, 212, Ottawa, Canada, 897, 1984.

Panizza, M.: Geomorphology and Seismic Risk, Earth Sci. Rev., 31, 43-54, 1991.

Sha, W. N. and Yang, Z. Z.: Numerical Prediction of Storm Surge and Wave, China Ocean Press, 1-28, 2004.

Taylor, T.: Sex, money and morality: prostitution and tourism in Southeast Asia, London, Zed Books, 1990.

UNDRO: Natural Disaster and Vulnerability Analysis, Office of the UN Disaster Relief Co-ordinator, Geneva, 1982.

Vale, L. J. and Campanella T. J.: The Resilient City: How Modern Cities Recover from Disaster, New York, Oxford University Press, 2005.

White, G. F. and Haas J. E.: Assessment of research on natural hazards, MIT Press, Cambridge, Mass, 1975.

Yang, G. S., Shi, Y. F., Zhang, C., and Liang, H. T.: Assessment of vulnerable scope to environment change in Jiangsu coastal plain, Acta Geographica Sinica, 55(4), 385-394, 2000.

Yang, H. T., Tian, S. Z., and Ye, L.: Catalog of Marine and Coastal Disasters in China (1949-1990), China Ocean Press, Beijing, China, 1-288, 1994.

Zhang, J. X., Huang, C. F., and Liu, X. L.: Geographical distribution and risk assessment of Typhoon storm surge disasters in coastal regions in Guangdong Province in 1949-2005, Journal of Basic Science and Engineering, 16(3), 393-402, 2008.

Zhang, W. Q., Huang, Z. G. and Lian, W. S.: The synthetic assessment of socio-economic impact of rising sea level in Guangdong coast region, Journal of Natural Disasters, 8(1), 78-87, 1999.

Zhao, Q. L., Xu, S. Y., Wang, J., Hu, B. B., Ye, M. W., and Liu, Y. L.: A Review of Risk Assessment of Storm surge on Coastal Cities, Progress in Geography, 26(5), 32-40, 2007. 